\section{Fecundity of Tetraploid $\times$ Diploid Crosses and Fertility of the Resultant Triploids in Salpiglossis sinuata}

\author{
Douglas C Needham ${ }^{1}$ and Homer T. Erickson \\ Department of Horticulture, Purdue University, West Lafayette, IN 47907
}

Additional index words. velvet flower, painted tongue

\begin{abstract}
Mean seed production in tetraploid $\mathrm{x}$ diploid crosses of Salpiglossis sinuata $\mathrm{R}$ et $\mathrm{P}$. was similar to that in diploid $\mathrm{x}$ diploid crosses, but germination of the resultant triploid seeds was low $(8 \%)$. Parental line selection resulted in some germination improvement. Triploid hybrids from these crosses were vigorous, with floral characteristics resembling tetraploids. The fertility indices of self-pollinations of triploids and pollinations by diploid and tetraploid plants were $<1,22$, and 6 , respectively, compared with 176 for diploid $\times$ diploid crosses. Thus, the self-pollinated triploids were virtually sterile.
\end{abstract}

Salpiglossis sinuata, a member of the Solanaceae, is a colorful, hardy annual whose value as a garden ornamental is limited because of its leggy growth, cleistogamous flowers (Lee et al., 1978), and somewhat limited blooming period. Cleistogamy can be eliminated genetically (Lee et al., 1976); however, modifications of growth habit and prolongation of flowering have not yet been achieved. Plant and floral characteristics of triploid salpiglossis are similar to those of tetraploids, both having more robust growth, darker foliage, and larger, showier flowers than diploids. This study was initiated to determine whether triploid seeds can be produced in quantity.

Triploids of most species are generally highly sterile. Notable examples are found in banana (Musa $\times$ paradisiaca L.) and seedless watermelon [Citrullus vulgaris (Thunb.) Matsum. Nakai]. Such sterility, with its absence of seed production, can prolong flowering. Among annual ornamentals, triploids have gained commercial acceptance primarily in marigolds, where the tetraploid "French" Tagetes patula L. is crossed with the diploid "African" Tagetes erecta L. Seeds are costly and germination tends to be low. Yield of triploid seed may be encumbered by abortion- of developing embryos in $4 \mathrm{x} x$ $2 \mathrm{x}$ crosses. This breakdown is attributed to genomic imbalance of the embryo and the endosperm that interferes with their correlative development (Brink and Cooper, 1947).

Received for publication 17 June 1991. Accepted for publication 4 Feb. 1992. Purdue Univ. Agricultural Experiment Station Journal Paper no. 12827. Mention of trade names in this publication does not imply endorsement by the Purdue Agr. Expt. Sta. of products named, nor criticism of similar ones not named. The cost of publishing this paper was defrayed in part by the payment of page charges. Under postal regulations, this paper therefore must be hereby marked advertisement solely to indicate this fact. dress: 360 Agricultural Hall, Dept. of Horticulture and Landscape Architecture, Oklahoma State Univ., Stillwater, OK 74078-0511.
'Assistant Professor of Floriculture. Current ad-
Marks (1966), observing that triploid embryos are often at a disadvantage during early development, coined the term "triploid block" in response to the rarity of triploids produced by the crosses of tetraploid and diploid Solanum chacoense Bitter. According to Johnston et al. (1980) and Johnston and Hanneman (1980, 1982), normal development of endosperm in Solanum, and likely in most angiosperms, depends on a ratio of 2 maternal : 1 paternal genome.

Highly inbred diploid $(2 \mathrm{n}=2 \mathrm{x}=44)$ salpiglossis lines P-1, P-2, P-3, P-4, and $\mathrm{P}-5$ were used as pollen parents, and highly inbred tetraploid $(2 \mathrm{n}=4 \mathrm{x}=88)$ lines $\mathrm{P}-6$, P-7, and P-8 (Erickson et al., 1982), as well as six tetraploid families (designated 9, 10, $11,12,13$, and 14), were included as seed parents.

Flowers serving as seed parents were emasculated before anthesis. Fresh pollen was applied directly from the anthers of flowers serving as pollen parents. The interploidy matings were analyzed to test seed parent and pollen parent influences on seed production and viability. Seeds of individual capsules were germinated on moistened, double-thickness 1 Whatman filter paper disks in 9-cm disposable petri dishes and incubated at 24C for 8 days. One-hundred seed, but not more than half the number in a capsule, were tested for germination. Germination is expressed as the percentage of seeds with exposed radicles.
Triploid progenies of three $4 \mathrm{x} \times 2 \mathrm{x}$ crosses (P-7 x P-3, P-6 x P-3, and P-7 x P-5) were evaluated for seed production and germination when selfed and when pollinated by five diploid and three tetraploid inbreds.

Production of seeds from tetraploid $\times$ diploid crosses. The number of seeds per capsule ranged from 37 to 518, with a mean of 222 , which is not significantly different than the mean for diploid $x$ diploid crosses (Table 1). Tetraploid seed parents and diploid pollen parents significantly $(P=0.001)$ influenced seed quantity (Table 2). Families 9 and 12 produced the most seeds per capsule. Pollination by parental lines P-2 or P-3 gave fewer seeds per capsule than that by $\mathrm{P}-1$, $\mathrm{P}-4$, or P-5. There was no parental line interaction on seed production.

Reciprocal crosses of $2 \mathrm{x} \times 4 \mathrm{x}$ Salpiglossis produced few seeds and none was viable, which concurs with Steere's (1932) findings in petunia crosses.

Germination of seeds form tetraploid $x$ diploid crosses. The germination percentage for seeds of $4 \mathrm{x} \times 2 \mathrm{x}$ crosses averaged $8 \%$ (Table 1), ranging from $0 \%$ to $20 \%$. General linear models procedure revealed a significant $(P=0.003)$ two-way parental line interaction on seed germination (Table 3 ) with P-6 $\times$ P-4, P-7 $\times$ P-3 or P-5, P- $8 \times$ P-5, and $14 \times \mathrm{P}-5$ producing triploid seeds with the highest germination percentage.

Fertility of triploid plants. Triploid plants from these crosses, when fertilized by pollen from diploids, had a mean of 22 viable seeds per pollination (fertility index). Those fertilized by pollen from tetraploids had a mean of six viable seeds per pollination, and triploid self-pollinations had a mean of less than one viable seed per pollination, partly because of the low incidence of capsule development (Table 1).

Chromosome counts were not taken of putative triploid plants in this study; however, all were essentially self-sterile with traits that were phenotypically triploid. An earlier cytological study had shown the reliability of these traits in identifying triploids (Steadman, 1980). Any tetraploids arising from unreduced gametes would be expected to be fertile. Among the large number of $4 \mathrm{x} x 2 \mathrm{x}$ plants we have grown, only one was fertile and it was confirmed to be tetraploid.

Reduced fertility of triploid plants appears to involve ovules and pollen. Pollination by diploids resulted in production of only $\approx 30 \%$
Table 1. Summary of seed production and germination in various ploidy levels of Salpiglossis.

\begin{tabular}{|c|c|c|c|c|}
\hline Pollination & $\begin{array}{c}\text { Capsules/ } \\
\text { pollinations (no.) }\end{array}$ & $\begin{array}{c}\text { Seeds/ } \\
\text { capsule (no.) }\end{array}$ & $\begin{array}{c}\text { Germination } \\
(\%)\end{array}$ & $\mathrm{FI}^{\mathbf{2}}$ \\
\hline $2 \mathrm{x} \times 2 \mathrm{x}$ & $15 / 15=100 \%$ & 207 & 85 & 176 \\
\hline $3 x \times 2 x$ & $103 / 130=79 \%$ & 63 & 44 & 22 \\
\hline $3 x \times 3 x$ & $7 / 134=5 \%$ & 21 & 32 & $<1$ \\
\hline $3 x \times 4 x$ & $67 / 83=81 \%$ & 39 & 19 & 6 \\
\hline $4 x \times 2 x$ & $536 / 546=98 \%$ & 222 & 8 & 17 \\
\hline $4 x \times 4 x$ & $135 / 145=93 \%$ & 84 & 81 & 63 \\
\hline Significance & & $* * *$ & $* * *$ & \\
\hline HSD $(0.05)$ & & 20.4 & 4.9 & \\
\hline
\end{tabular}

${ }^{\mathrm{z}} \mathrm{FI}=$ Fertility index $=$ (mean number seeds) (percentage of pollination that formed capsules) (percentage of seed that germinated). ***Significant at $P=0.001$ determined by $\mathrm{F}$ test. 


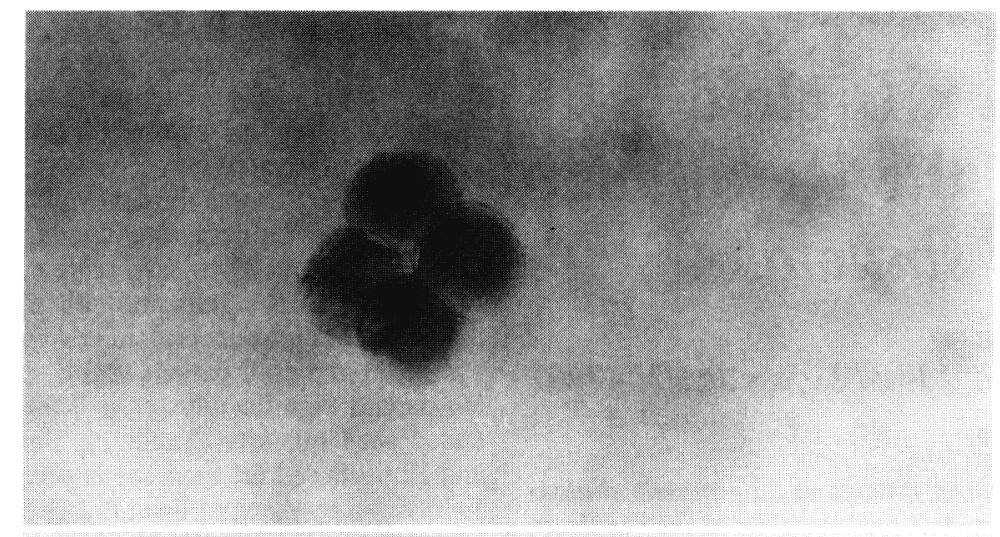

Table 2. Parental effect on triploid seed production in Salpiglossis.

\begin{tabular}{|c|c|}
\hline Parent & $\begin{array}{c}\text { Mean seed } \\
\text { production (no.) }\end{array}$ \\
\hline \multicolumn{2}{|l|}{$4 x$ seed } \\
\hline $\begin{array}{c}\text { P-6 } \\
\text { P-7 } \\
\text { P-8 } \\
9 \\
10 \\
11 \\
12 \\
13 \\
14\end{array}$ & $\begin{array}{l}214 \\
195 \\
140 \\
281 \\
219 \\
147 \\
262 \\
221 \\
201\end{array}$ \\
\hline \multicolumn{2}{|l|}{$2 \mathrm{x}$ pollen } \\
\hline $\begin{array}{l}\mathrm{P}-1 \\
\mathrm{P}-2 \\
\mathrm{P}-3 \\
\mathrm{P}-4 \\
\mathrm{P}-5\end{array}$ & $\begin{array}{l}235 \\
200 \\
201 \\
228 \\
245\end{array}$ \\
\hline Seed parent & $* * *$ \\
\hline $\begin{array}{r}\text { HSD }(0.05) \\
\text { Pollen parent }\end{array}$ & $\begin{array}{l}34.6 \\
* * *\end{array}$ \\
\hline HSD $(0.05)$ & 22.7 \\
\hline Seed parent $\times$ pollen parent & NS \\
\hline
\end{tabular}

(37/21C day/night). Using this pigmentation as an indicator, it was apparent that diploid seed developed more uniformly than those in $4 x \times 2 x$ crosses. In these crosses, some fertilized ovules became intensely purple while others were only faintly colored or even hyaline in the same capsule. We do not know if this differential development is correlated with eventual mature seed viability.

A reasonable explanation for low viability of $4 \mathrm{x} \times 2 \mathrm{x}$ seeds is endosperm breakdown, leaving the embryo with little food reserve during germination. Presence of shrunken, mature seeds supports this view, since Salpiglossis seeds normally retain substantial endosperm at maturity. Johnston et al. (1980) proposed an endosperm balance number (EBN) hypothesis to explain why interploidy crosses, such as $4 \mathrm{x} \times 2 \mathrm{x}$, in Solanum species may result in inviable seeds. Although Salpiglossis, as another genus of the Solanaceae, may be affected by EBN, embryo rescue techniques indicated that other factors also may be affecting seed viability. In vitro culture of triploid Salpiglossis seeds and embryos (S.L. Kitto, personal communication) determined that immature 11-day-old and

Fig. 1. Tetrads of diploid plants (top), tetraploid plants (center), and triploid plants (bottom). complete tetrads, resulting from pollen abortion, are frequently observed in triploid plants (botton

of the number of seeds produced from a diploid self-fertilization. This result probably reflects the level of abnormal ovules produced by the triploid plants. Although Avers (1954) found triploid asters (Aster shortii Lindl. $\times A$. cordifolius L.) to be fertile and believed that the univalent ones underwent two equational divisions, the low fertility of triploid salpiglossis ovules probably results from chromosome unbalance. The pollen of triploids was abnormal, showing abortion and other abnormalities (Fig. 1, bottom). Only $5 \%$ of triploid self-pollinations were suc- cessful, and very few viable seeds developed (Table 1).

The rate of capsule development in $4 \mathrm{x} x$ $2 \mathrm{x}$ crosses was slightly accelerated compared with $2 \mathrm{x} \times 2 \mathrm{x}$ crosses, and the capsules, which swelled to their maximum dimensions within 7 days, often matured a few days earlier but contained more shrunken seeds than those of $2 \mathrm{x} \times 2 \mathrm{x}$ crosses (Fig. 2). Embryos of the parental lines used in this study developed a rich purple pigmentation shortly before the seedcoat began to harden at 9 to 12 days after fertilization in the high summer temperatures older intact seeds germinated inconsistently on media containing $0 \%, 2 \%, 4 \%$, or $8 \%$ sucrose; however, excised 11-day-old and older embryos were viable and grew on all sucrose concentrations tested. Thus, triploid embryo growth may be hindered not only by EBN, but also by the thicker seedcoat, since seeds were produced on tetraploid plants and the seedcoat is maternal tissue. Such tissues are normally heavier in tetraploids than in diploids and, as such, may present a physical barrier to germination of triploid embryos. This condition exists in triploid watermelons grown for seedless fruit (Kihara, 1951), and seed scarification is recommended for en- 
Table 3. Parental effect on triploid seed germination percentage in Salpiglossis.

\begin{tabular}{|c|c|c|}
\hline $\begin{array}{l}4 \times \text { Seed } \\
\text { parent }\end{array}$ & $\begin{array}{c}2 \mathrm{x} \text { Pollen } \\
\text { parent }\end{array}$ & $\begin{array}{c}\text { Mean } \\
\text { germination } \\
(\%)^{2} \\
\end{array}$ \\
\hline \multirow[t]{5}{*}{ P-6 } & P-1 & 13.4 \\
\hline & $P=2$ & 8.6 \\
\hline & P-3 & 14.2 \\
\hline & P-4 & 15.8 \\
\hline & P-5 & 11.6 \\
\hline \multirow[t]{5}{*}{ P-7 } & $P-1$ & 8.6 \\
\hline & P-2 & 9.0 \\
\hline & P-3 & 19.4 \\
\hline & $P-4$ & 12.6 \\
\hline & P-5 & 18.2 \\
\hline \multirow{5}{*}{ P-8 } & P-1 & 10.4 \\
\hline & P-2 & 8.0 \\
\hline & P-3 & 9.4 \\
\hline & $P-4$ & 13.5 \\
\hline & P-5 & 19.8 \\
\hline \multirow[t]{5}{*}{9} & P-1 & 5.9 \\
\hline & P-2 & 3.4 \\
\hline & P-3 & 7.6 \\
\hline & $P-4$ & 5.8 \\
\hline & P-5 & 7.8 \\
\hline \multirow[t]{5}{*}{10} & P-1 & 7.5 \\
\hline & P-2 & 7.3 \\
\hline & P-3 & 4.6 \\
\hline & P-4 & 9.1 \\
\hline & P-5 & 12.9 \\
\hline \multirow[t]{5}{*}{11} & P-1 & 4.3 \\
\hline & P-2 & 0.8 \\
\hline & P-3 & 1.0 \\
\hline & P-4 & 2.5 \\
\hline & P-5 & 7.5 \\
\hline \multirow[t]{5}{*}{12} & P-1 & 4.6 \\
\hline & $\mathrm{P}-2$ & 5.6 \\
\hline & P-3 & 3.9 \\
\hline & $P-4$ & 4.3 \\
\hline & P-5 & 5.2 \\
\hline \multirow{5}{*}{13} & P-1 & 7.9 \\
\hline & P-2 & 7.0 \\
\hline & P-3 & 7.6 \\
\hline & $P-4$ & 6.9 \\
\hline & P-5 & 8.5 \\
\hline \multirow[t]{5}{*}{14} & P-1 & 15.2 \\
\hline & P-2 & 8.3 \\
\hline & $P-3$ & 7.8 \\
\hline & P-4 & 13.2 \\
\hline & P-5 & 15.9 \\
\hline \multirow{2}{*}{\multicolumn{2}{|c|}{$\begin{array}{l}\text { Seed parent } \times \text { pollen parent } \\
\text { HSD }(0.05)\end{array}$}} & $* *$ \\
\hline & & 4.5 \\
\hline
\end{tabular}

${ }^{2}$ Value is mean of at least 20 replications.

" Significant at $P=0.01$ determined by $\mathrm{F}$ test.

hanced germination. Seed scarification was ineffective in Salpiglosssis. Low germination is likely a consequence of a combination of factors.

There was no correlation between production of triploid seeds and germination percentage, but this investigation involved a limited number of parental combinations in a species that is notable for its genetic variability. The production of triploid seeds will become economically feasible only if a substantial number of viable seeds are produced per pollination. Since parental line effects exist, one may be able to increase the fertility index by rigorous parental line selection.
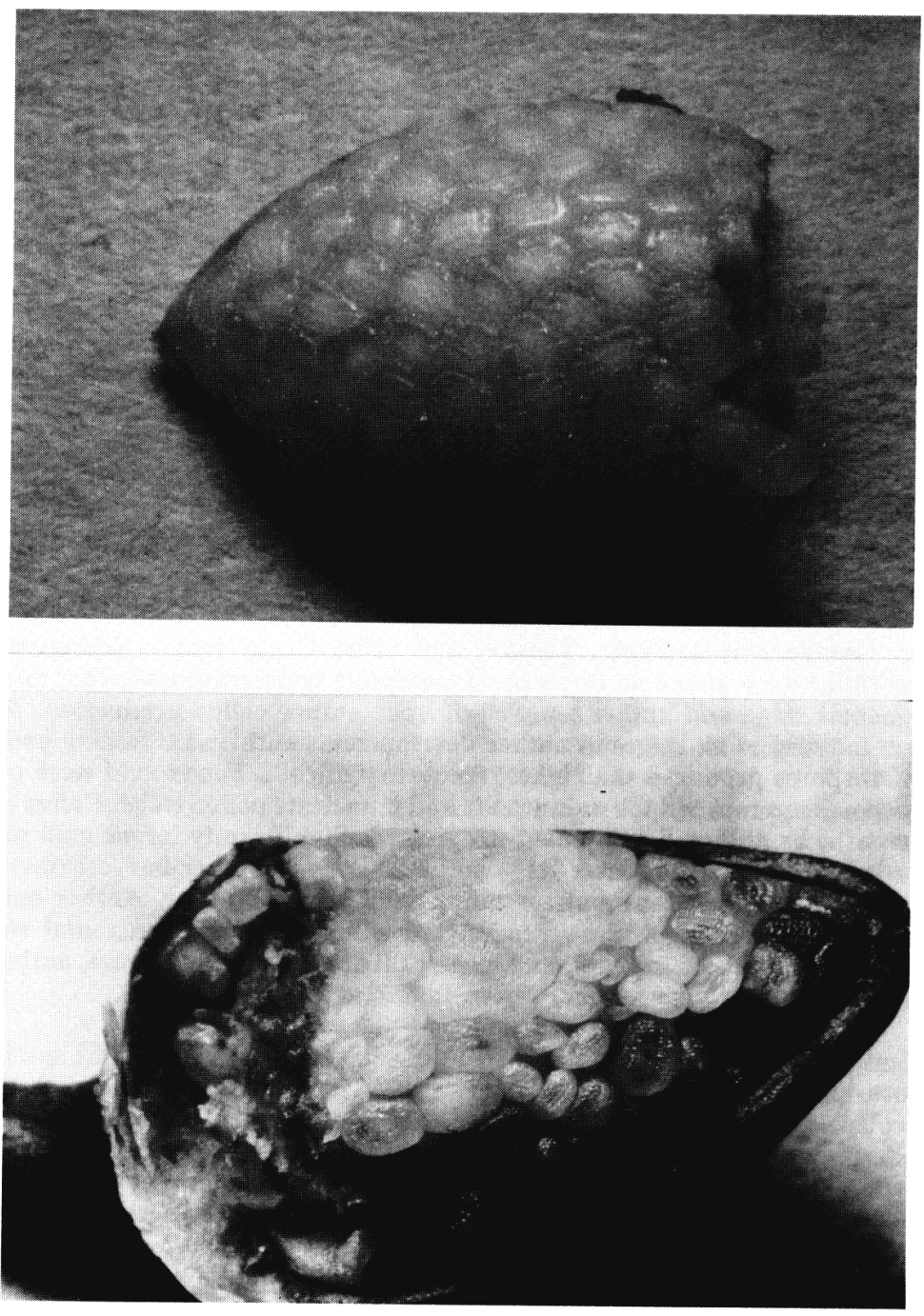

Fig. 2. Embryonic development of diploid (top) and triploid seeds (bottom) at 9 days after fertilization.

\section{Literature Cited}

Avers, C.J. 1954. Chromosome behavior in fertile triploid aster hybrids. Genetics 39:117-126.

Brink, R.A. and D.C. Cooper. 1947. The endosperm in seed development. Bot. Rev. 13:423541 .

Erickson, H.T., J. Steadman, C.W. Lee, and J. Janick. 1982. P-P Diploid and tetraploid salpiglossis germplasm. HortScience 17(2):260.

Johnston, S.A., T.P.M. den Nijs, S.J. Peloquin, and R.E. Hanneman, Jr. 1980. The significance of genic balance to endosperm development in interspecific crosses. Theor. Applied Genet. 57:5-9.

Johnston, S.A. and R.E. Hanneman, Jr. 1980. Support of the endospenn balance number hypothesis utilizing some tuber-bearing Solanum species. Amer. Potato J. 57:7-14.

Johnston, S.A. and R.E. Hanneman, Jr. 1982. Manipulations of endosperm balance number overcome crossing barriers between diploid So- lanun species. Science 217:446-448.

Kihara, H. 1951. Triploid watermelons. Proc. Amer. Soc. Hort. Sci. 58:217-230.

Lee, C.W., H.T. Erickson, and J. Janick. 1976. Inheritance of cleistogamy in Salpiglossis sinuata. J. Hered. 67:267-270.

Lee, C.W., H.T. Erickson, and J. Janick. 1978 Chasmogamous and cleistogamous pollination in Salpiglossis sinuata. Physiol. Plant. 43(3):225-230.

Marks, G.E. 1966. The origin and significance of intraspecific polyploids: Experimental evidence from Solanum chacoense. Evolution 20:552-557.

Steadman, J.S. 1980. Seed production and cytogenetics of induced polyploids of Salpiglossis sinuata. MS Thesis, Purdue Univ., West Lafayette, Ind.

Steere, WC. 1932. Chromosome behavior in triploid petunia hybrids. Amer. J. Bot. 19:340357. 